\title{
NURCHOLISH MADJID'S IDEA OF INCLUSIVE THEOLOGY IN ISLAM
}

\author{
Munir A. Muin \\ Faculty of Ushuluddin Sunan Gunung Djati \\ State Islamic University of Bandung, Indonesia \\ muniramuin@uinsgd.ac.id
}

\begin{abstract}
Nurcholish Madjid was one of Indonesian Muslim intellectuals who had shaped specific school of Islamic thought known as neomodernism. One of contemporary issues that he was concerned with was the problem of religious plurality, which was a fact in Indonesian religious life and had been debated among Indonesian Muslim scholars before him. However, at his era, the discussion of such an issue became more controversial and attracted wider debate. This is because he interpreted "Islam," which is commonly understood as religion of the followers of Prophet Muhammad, to mean "surrender" to God's will which is at the heart of all prophetic religions before him. In addition, he extended the concept of people of the book (ahl al-kitab), which includes exclusively the adherents of Judaism and Christianity as traditionalists understand, to cover other religious traditions such as Hinduism, Buddhism, and so on. Drawing greatly on Nurcholish's works, this article argues that his theology of religious pluralism can be categorized as inclusive, which is different from exclusivism.
\end{abstract}

Keywords: Inclusive Theology, Islam, Indonesia, Neomodernism

\section{INTRODUCTION}

Nurcholish Madjid was a prominent Indonesian Muslim thinker as well as a controversial figure. His thought often surprises many people and challenges established understanding of religious concepts. Wearing jilbāb (veil) which is understood by many people as an obligation for women, for example, is interpreted by Nurcholish merely as a "mantel." The word "Allah" in Là ilāha illā Allāh is translated simply to mean God, not Allah as is usually translated. This translation has been a target of Husnan's

\footnotetext{
1 Nurcholish Madjid, “Interview,” “Interview,” Matra Magazine, 77 (December), 1992; idem, Dialog Keterbukaan: Artikulasi Nilai Islam dalam Wacana Sosial Politik Kontemporer (Jakarta: Paramadina, 1998), 1356 .
} 
critique. $^{2}$

Nurcholish's (so is he referred to, because Madjid is his father's name) thought has become a focus of several scholarly studies. Kamal Hassan, for example, focuses on Nurcholish's idea of secularization as a response to modernization which is the main target of New Order's development in Indonesia. ${ }^{3}$ Fachry Ali and Bahtiar Effendy, ${ }^{4}$ on the other hand, emphasize Nurcholish's role in the Renewal of Islamic thought when they describe the development of Islamic thought in Indonesia. Another scholar who is concerned with Nurcholish's thought is Greg Barton. Similar to the focus of Ali's and Effendy's scholarship, Barton also explores Nurcholish's Islamic thought, but with emphasis mostly on the typology of his thought. ${ }^{5}$

Apart from these studies, Nurcholish's position toward religious pluralism does not attracts serious attention from scholars. In fact, as far as Nurcholish's thought is concerned, religious tolerance and pluralism make up the most part of his works. For this reason, Mark R. Woodward calls Nurcholish one of Indonesia's most daring theologians and a vehement advocate of religious tolerance. Moreover, Woodward argues that "his visionof Islam is pluralistic." Woodward's assessment of Nurcholish falls short, however, since it does not explain in detail whether Nurcholish should be considered a pluralist or an inclusivist thinker.

This paper examines Nurcholish's response to religious pluralism, describing his interpretation of the meaning of "Islam" and his notion of people of the book (ahl al-kitāb). Since he interprets the religious concepts contained in the scripture in a contextual framework, his thought can be considered theological rather than philosophical. Before describing his discussion of scriptural concepts, however, I will begin by examining his intellectual background and activities.

\section{MATERIALS AND METHODS}

Basically, this study is philosophico-theological in nature. This is because inclusivism can be dealt with in philosophy, especially philosophy of religion, as well as in theology. Therefore, the method used in this study is analytic, in that this study will analyze the logic of ideas proposed by the figure under discussion and to elucidate the meaning of his concepts. ${ }^{7}$ As

\footnotetext{
2 Ahman Husnan, Jangan Terjemahkan al-Qur'an menurut Visi Injil dan Orientalis (Solo: UlulAlbab Press, 1987).

${ }^{3}$ Muhammad Kamal Hassan, Muslim Intellectual Responses to the New Order Modernization in Indonesia. Kuala Lumpur: Dewan Bahasa dan Pustaka, 1982.

${ }^{4}$ Fachry Ali and Bahtiar Effendy, Merambah Jalan Baru Islam: Rekonstruksi Pemikiran Islam Masa Orde Baru (Bandung: Mizan, 1984).

${ }^{5}$ Greg Barton, "Neo-Modernism: a Vital Synthesis of Traditionalist and Modernist Islamic Thought in Indonesia," Studia Islamika, 2:3 (1995): 1-75).

${ }^{6}$ Mark Woodward, "Nurcholish Madjid," in The Oxford Encyclopedia of Modern Islamic World, ed. John L. Esposito (New York and London: Oxford University Press 1995), 3: 254.

${ }^{7}$ Michael Peterson et.al., Reason and Religious Belief: an Introduction to the Philosophy of Religion (New
} 
for the materials, there are two kinds of sources used in this study: primary and secondary. The primary sources consist of Nurcholish's first hand works relevant to the questions raised in this study, while secondary sources include all writings that deal exclusively with Nurcholish's thought in general and with his ideas of inclusive theology in particular.

\section{RESULTS AND DISCUSSION}

\section{A. Biographical Sketch of Nurcholish Madjid}

NurcholishMadjid was bom in Jombang, East Java, on March 17, 1939. After attending a secular public Elementary School (Sekolah Rakyat) and religious school, Madrasah al-Wataniyyah (which, incidentally, was headed by his father), he went on to study at Pesantren Darul 'Ulum Rejoso two years, ${ }^{8}$ then at Pondok Modem Gontor, East Java, about six years. Nurcholish was strongly influenced by the pesantren's (boarding school) ground-breaking synthesis of traditional learning and modern education. This pesantren called modern because, among other things, it has no affiliation with any socio-political or religious organization with the motto: "Above and for all groups."

In the early 1960s, Nurcholish began his tertiary studies at the Faculty of Letter (kulliyat al-ādāb) at the State Institute for Islamic Studies (IAIN, now State Islamic University, UIN), Syarif Hidayatulah, Jakarta. After two years of study, he started participating in the activities of the Himpunan Mahasiswa Islam (Islamic Student Organization, HMI), the largest student organization in Indonesia that presided over by secular university students. ${ }^{10}$ In 1967, Nurcholish was elected president of the HMI, thereby becoming the first and the only president who did not come from the secular university. More surprisingly, two years later he was reelected. Again, Nurcholish became the first and the only person who headed the organization in two terms. ${ }^{11}$ Beside his activities at HMI during this period, he also held positions as the President of the Union of Southeast Asia Muslim Students and as Deputy Secretary General of the International Islamic Federation of Student Organization (IIFSO). ${ }^{12}$

In 1968, Nurcholish finished his tertiary study with a thesis entitled: al-Qur'ān: 'Arabiyyun Lughatan wa 'Älamiyyun Ma'nan (al-

\footnotetext{
York-Oxford: Oxford University Press, 1991), 8.

${ }^{8}$ Greg Barton, "Indonesia's Nurcholish Madjid and Abdurrahman Wahid as Intellectuals", Studia Islamika, 4:1 (1997), 46.

9 H.A. Saifullah, "Daarussalaam: Pondok Modem Gontor," in Pesantren dan Pembaharuan, ed. M. DawamRahardjo. Jakarta: LP3ES,1988), 134-154; Lance Castles, "Notes on the Islamic School at Gontor," Indonesia, 1 (1996); Mastuhu, Dinamika Sistem Pendidikan Pesantren: Suatu Kajian tentang Unsur dan Nilai Sistem Pendidikan Pesantren (Jakarta: INIS, 1994).

${ }^{10}$ Madjid, "The Issue of Modernization among Muslims in Indonesia: From a Participant's Point of View," in What is Modern Indonesian Culture?, ed. Gloria Davis (Athens: Ohio University Press, 1979), 143.

11 Madjid, "The Issue of Modernization," 143.

${ }^{12}$ Barton, "Indonesia's Nurcholish Madjid," 47.
} 
Qur'an: "Arabic in language, universal in meaning"). ${ }^{13}$ In the same year, he also had a chance to visit the United States as a student leader, sponsored by the Council for Leaders and Specialists (CLS) in Washington. On his way back from the United States, he visited several Middle Eastern countries, such as Turkey, Lebanon, Syria, Iraq, Kuwait, Saudi Arabia, Sudan and Egypt. Nurcholish's intellectual capacity and mastery of Arabic so impressed his audience that the government of Saudi Arabia officially invited him to undertake the hajj (pilgrimage) in March of 1969. After his return to Jakarta, he dedicated his time to writing his manifesto, based on his experiences in Indonesia and his observation and encounters with political groups of Middle Eastern countries; Nilai-nilai Dasar Perjuangan (The Basic Values of Struggle) later became the ideological manual for members of the organization. ${ }^{14}$

In the early years of the 1970s, modernization was the main program of the New Order government, and became a controversial topic of discussion among Indonesian intellectuals. MuchtarLubis and Rosihan Anwar, the two most prominent Indonesian journalists of the time, argued strongly for modernization in their respective daily newspapers, Indonesia Raya (Indonesia the Great) and Pedoman (Guideline). Since modernization implies pragmatism, rationalism and secularism, Indonesian Muslim groups were extremely hostile towards such a notion. Therefore, for their rivals, Muslims, and even HMI, represent a challenge to modernization. ${ }^{15}$ In response to the issue, Nurcholish argues that modernization, in principle, is rationalization, and, therefore, it is obligatory for Muslims to realize it; he substantiates this injunction by reciting Quranic verses. ${ }^{16}$ Several critiques which challenged his ideas came to the fore.

Nurcholish's most controversial ideas were highlighted when he addressed the four most important organizations of young Indonesian Muslims in January of 1970, specifically HMI, Pelajar Islam Indonesia (Islamic Student Association, PII), Gerakan Pemuda Islam (Muslim Youth Movement, GPI) and Persatuan Sarjana Muslim Indonesia (Indonesia Muslim Scholars Association, Persami). Dr. Alfian was initially invited to address the congregation of young Indonesian Muslims, but when he declined, the sponsors asked Nurcholish to replace him. In Dr. Alfian's stead, Nurcholish presented a paper entitled, "Keharusan Pembaruan Pemikiran Islam dan Masalah Integrasi Umat" (The Necessity of Renewing Islamic Thought and the Problem of Integration of the Ummah). In this paper, he proposed a concept of secularization with the following slogan: "Islam, yes, Islamic party, no". What he meant by secularization was not

\footnotetext{
${ }^{13}$ Komarudin Hidayat, "Kata Pengantar" [Preface] to Nurcholish Madjid's Islam Agama Peradaban: Membangun Makna dan Relevansi Doktrin Islam dalam Sejarah (Jakarta: Paramadina, 1995), vi.

${ }^{14}$ Madjid, "The Issue of Modernization," 143.

${ }^{15}$ Madjid, "The Issue of Modernization," 144.

${ }^{16}$ Madjid, "The Issue of Modernization," 172-3.
} 
an application of secularism; but rather a devaluation of what is not Islamic, but may be considered Islamic by many people. ${ }^{17}$ Therefore, in his view, an Islamic party is not identical with Islamic values, and, hence, parties should be desacralized. Again, his ideas became the target of several strong critiques. ${ }^{18}$ In 1974, Fazlur Rahman and Leonard Binder came to Jakarta as part of a long-term research project funded by the Ford Foundation. They were in search of Indonesian participants to partake in a half-year seminar program at the University of Chicago. Initially, they had intended to invite senior modernist leader H.M. Rasyidi, who at the time was one of Nurcholish's strongest critics in the secularization debate. Ironically, Rahman and Binder decided that Rasyidi was 'too old', and decided to opt for Nurcholish instead. As a result, Nurcholish spent seven months at the University of Chicago in 1976, participating in an international research seminar program on Islam and social change. ${ }^{19}$ Impressed with his young charge, Nurcholish was offered a chance by Rahman and Binder to stay at Chicago for postgraduate studies. He accepted this opportunity, with the proviso that he would return to the University of Chicago in 1978; he planned to take part in the 1977 election campaign in Indonesia. It is interesting to note that, despite his critique of merging politics and religion, he compaigned for PartaiPersatuan Pembangunan (United Development Party, PPP), the fused Muslim party. The reason for his involvement in PPP's campaign is that he recognized Indonesia need for strong opposition parties against the dominant Golongan Karya (Functional Group, Golkar). He believed that PPP and Partai Demokrasi Indonesia (Indonesian Democratic Party, PDI) should be strengthened to make a front against Golkar. Nurcholish argued that Indonesian democracy is like a becak (a three wheeled pedicab); at the time two of the three wheels have flat tires, and his job was to pump one of them up, so the becak (that is, democracy) can run properly. ${ }^{20}$ This is also the reason that his idea of modernization was not simply a justification of the New Order's conceptualization of modernization. ${ }^{21}$

Nurcholish arrived at the University of Chicago in 1978, expecting to pursue a doctorate in political science with Leonard Binder. However, he was persuaded by Rahman to undertake research in Islamic Studies on the grounds that the Muslim world needed modem scholars of Islam more than

\footnotetext{
${ }^{17}$ On the debate of secularization of Nurcholish Madjid, see Mun'im Sirry, "Secularization in the Mind of Muslim Reformists: A Case Study of Nurcholish Madjid and Fouad Zakaria," Journal of Indonesian Islam, 1: 2 (2007): 323-355.

${ }^{18}$ H.M. Rasyidi, Koreksi terhadap Drs. Nurcholish Madjid tentang Sekularisasi (Jakarta: Bulan Bintang, 1972); Endang Saefudin Anshari, Kritik atas Paham Sekularisasi dan Pembaharuan Drs. Nurcholish Madjid (Bandung: Bulan Sabit, 1973).

${ }^{19}$ Barton, "Indonesia's Nurcholish Madjid," 49.

${ }^{20}$ Barton, "Indonesia's Nurcholish Madjid," 49-50.

${ }^{21}$ Azyumardi Azra, "Cak Nur: Neo-Modemis atau Neo-Traditionalis” (Unpublished paper, n.d.).
} 
it needed political scientists. ${ }^{22}$ Under Rahman's supervision, Nurcholish completed his degree in 1984 with a dissertation entitled: Ibn Taymiyya on Kaläm and Falsafa: a Problem of Relation between Reason and Revelation.

When Nurcholish returned to Indonesia in 1985, he participated in teaching staff at his alma mater, IAIN Syarif Hidayatullah Jakarta. He also held a position at the Indonesian Academy of Sciences (Lembaga Ilmu Pengetahuan Indonesia, LIPI). Further, accompanied by his friends from the Renewal Movement, such as Utomo Dananjaya and Usep Fathuddin, he established a socio-educational organization called YayasanWakaf Paramadina (Foundation). Initially, this institute was strongly criticized on the grounds that it focused too narrowly on the middle and upper class of Abangan. In addition, due to the fact that the activities of the institute often took place at a luxurious hotel, Nurcholish's critics declared it must be funded by "Zionist propaganda." The institute's main activity is the Religious Studies Club (Klub Kajian Agama), a monthly seminar which focuses on a religious theme. Two papers which address certain aspects of religion and modem life are presented in each seminar. The second paper is normally presented by Nurcholish. Most of his books are compilations of these papers.

Based on this foundation, he and his friend founded a university, called University of Paramadina, where he served as the rector during the rest of his life. Moreover, as a national figure, he had a significant role in nation building, especially when Indonesia was suffered from economic and political crises in 1998, which resulted in what was known as reformasi era (reform). He had served as the head of National Commission for General Election in the first period. Since 2004, his health became worse and in August 2005 he passed away because of the failure of heart transplantation. ${ }^{23}$

\section{B. Between Neo-modernist and Neo-traditionalist}

Nurcholish's important position and contribution to Indonesian problems in general, and Islamic thought in particular, have become the focus of several studies. Kamal Hassan, for example, examines Nurcholish's response to modernization, and ultimately identifies him as an "idealistaccommodationalist." ${ }^{24}$ This is because Nurcholish understands modernization as an application of Islamic teachings that requires Muslims to devise themselves with an accurate approach toward their affairs.

William Liddle, on the other hand, categorizes Nurcholish, and those who are in line with his political perspectives, as a substantialist thinker whose understanding of the Quran is based on the spirit of its

\footnotetext{
${ }^{22}$ Barton, "Indonesia's Nurcholish Madjid," 50.

${ }^{23}$ Kompas, 30 August 2005; Tempo, 11 September 2005)

${ }^{24}$ Hassan, Muslim Intellectual Responses, 97.
} 
teachings, rather than on a literal understanding. This categorization differentiates Nurcholish's method of interpreting the Quran from those who interpret it literally, and apply its tenets rigidly, as represented by Media Dakwah Magazine. Liddle identifies Media Dakwah magazine as a fundamentalist or scripturalist movement. ${ }^{25}$

Another categorization of Nurcholish is made by Fachry Ali and Bahtiar Effendy when describing the development of religious thought in 1970s Indonesia. According to their scholarship, Nurcholish is one representative of a neo-modernist ${ }^{26}$ trend of thought in Indonesia. The rationale underlying their categorization is that Nurcholish tries to make ijtihād by combining the traditional and modernist trends represented by Nahdatul 'Ulama and Muhammadiyah respectively. ${ }^{27}$ Following the typology of Ali and Effendy, Greg Barton also refers to Nurcholish as a neo-modernist thinker. Criticizing Liddle's categorization of Nurcholish, Barton argues that one of the requirements of a neo- modernist thinker is the combination of traditional and modem thought, while substantialist thinkers do not necessarily require such criteria. In this regard, Nurcholishis better categorized as a neo-modernist thinker for his mastery of both classical and modem thought. ${ }^{28}$

However, if we analyze Nurcholish's thought in the light of Rahman's neo-modernist perspective, this categorization does not exactly apply. What should be emphasized in the neo-modemist perspective is a sound methodology for studying the Qur'an. This methodology, in Rahman's view, include: to see that moral objectives and principles are concretely embodied in the Qur'an, to critically analyze the sociohistorical background, and to interpret Quranic legislation so as to yield new laws for the present situation. ${ }^{29}$ To some extent, Nurcholish has met the criteria to be a neo-modernist thinker. But his attitude toward the hadith is not always critical. It is for this reason that Azyumardi Azra has objectsts to categorization of Nurcholish into neo-modernist trend of thought. Azra argues that Nurcholish cannot be categorized into one trend; he can also be identified as neo-traditionalist thinker. ${ }^{30}$ As Nasr states, the neo-traditionalist thinker is a Muslim scholar whose duty is "first and foremost to present to modem context the traditional truths that are available in the tradition, but half forgotten by Westernized educated

\footnotetext{
${ }^{25}$ William Liddle, Leadership and Culture in Indonesia Politics (Sydney: Asian Studies Association of Australia, 1996), 267-70.

${ }^{26}$ Fazlur Rahman, "Islam: Challenge and Opportunity," in Islam: Past Influence and Present Challenge, ed. Alford T. Welch and Pierre Cachia (New York: Edinburgh University Press, 1979), 326.

${ }^{27}$ Ali and Effendy, Merambah Jalan Baru, 170-1, 179-80.

${ }^{28}$ Barton, "The Impact of neo-Modernism on Indonesia Islamic Thought," 147-8.

${ }^{29}$ Rahman, "Islam: Challenge and Opportunity," 325-6.

${ }^{30}$ S.H. Nasr, Traditional Islam in the Modern World (London: KPI, 1987), $11-22$.
} 
Muslims. This means interpreting them without betraying them" ${ }^{31}$ In this respect, neo-traditionalist also applies to Nurcholish thought.

Based on this discussion, it is difficult to identify Nurcholish's thought into one single categorization exactly. This is due to the fact that his thought itself develops and evolves from time to time in accordance with social and historical change. In thel970s, for example, he proposed controversial terms such as "secularization", "liberalization" and so on, but later he avoided using controversial terms. Nurcholish states:

I wished that I had never committed such a tactical blunder that manifest in my speech on January 2, 1970. It was socially expensive, and we suffered almost irreparable damage to our reputation within the Muslim community. If we were able to go back in time, I would follow my previous methods, i.e., penetration pacifique, in introducing ideas. ${ }^{32}$

This confession indicates the possibility of changing of Nurcholish's position in trends of Islamic thought. In other words, the "one for all" categorization of anyone's thought is inappropriate, including Nurcholish's thought.

\section{Inclusive Theology in Nurcholish's Thought The Meaning of "Islam"}

For many people, Muslims and non-Muslims alike, the word "Islam" is nothing other than the religion revealed by God through the Prophet Muhammad. However, according to Cak Nur, "Islam" in its generic meaning is surrender or submission (al-istisläm) to One God. ${ }^{33}$ Islam is also a mode of existence of all beings in the universe. This means that, in principle, all existents in the universe surrender to God consciously or unconsciously. Plants, animals and other natural beings surrender unconsciously to God's Will and Plan (sunnat Alläh), so that they live harmoniously and peacefully. Human beings naturally surrender to God's Will because they have fitrah, that is, an intuitive ability to discern between right and wrong, true and false, good and bad. This fitrah leads them to have a natural inclination toward the good, the true and the sacred (which is called hanafiyyat al-samhah). Therefore, if they want to live peacefully they should follow their fitrah, that is, al-isläm. Only through alisläm can human beings acquire peace and salvation (salämah) as other beings do. Contrariwise, if they live against their fitrah or al-islam, they will never acquire peace and salvation, but will live in conflict instead. In

\footnotetext{
${ }^{31}$ S.H. Nasr, Islamic Life and Thought (Albany, NY: State University of New York, 1976), 32.

${ }^{32}$ Madjid, "The Issue of Modernization," 151-2.

${ }_{33}$ Madjid, Islam Agama Peradaban: Membangun Makna dan Relevansi Doktrin Islam dalam Sejarah (Jakarta: Paramadina, 1995), 2; idem, Islam, Kemodernan dan Keindonesiaan (Bandung: Mizan, 1987), 47; idem, Islam, Doktrin dan Peradaban, 181.
} 
other words, they are acting against God's "blueprint" and their own nature.

Nurcholish quotes the Qur'an to corroborate his position:

Do they seek for other than the Religion of Allah? While all creatures in the heavens and on earth have, willing or unwilling, bowed to His Will (accepted al-isläm), and to Him shall they all be brought back. Say: "We believe in Allah, and in what has been revealed to us and what was revealed to Abraham, Isma'll, Isaac, Jacob and the Tribes, and in (the Books) given to Moses, Jesus, and the Prophets, from their Lord. We make no distinction between one and another among them, and to Allah do we bow our will (in Islam)". If anyone desires a religion other than al-isläm (submission to Allah), never will it be accepted of him; and in the Hereafter he will be in the ranks of those who have lost (all spiritual good). ${ }^{34}$

"Islam" for Nurcholish is qualified as natural human submission to God. Whoever follows his or her fitrah or al-isläm regardless of space and time can be considered a Muslim, or, to use Mutahhari's term, a Muslim fitri (natural Muslim). ${ }^{35}$ However, human beings also have weakness, that is, to see the long-term consequences of actions due to the lure of shortterm expediences. In other words, the desires of short-term expedience often leads them to ignore their natural submission (al-islam) to God. ${ }^{36}$ For this reason, He sent prophets and messengers to human beings to remind them of their fitrah (nature) to surrender to their Creator.

Nurcholish also argues that "Islam" is not a specific religion for the Prophet Muhammad's followers, but rather the religion of all prophets revealed by God throughout the history of human beings before the Prophet Muhammad. The Qur'an, Nurcholish argues, recognizes Abraham (Quran, 3:67), Jacob and his descendents (Quran, 2: 132), Joseph (Quran, 12: 101), Nuh (Quran, 10: 72-3), Lut (Quran, 51:35-6), Jesus and his disciples (al-hawāriyyūn) (Quran, 3: 52), and even Pharaoh's sorcerers who later followed Moses (Quran, 7: 126), as Muslims (al-muslimūn). Those prophets and people lived long before the advent of the Prophet Muhammad, but the Quran acknowledges them as Muslims. This indicates that "Islam", which means submission to God, is a religion of all prophets. $^{37}$ In other words, the message of all prophets is the same, that is,

\footnotetext{
34 Abdullah Yusuf Ali, The Holy Qur'an: Text, Translation and Commentary (Maryland, USA: Amana Corporation, 1989), 149-50.

35 Murtạ̄ā Muṭahharī, Al-'Adl al-Ilāhī, Arabic trans. by M. 'Abd al-Mun'im al-Khaqqani (Beirut: Muassasat al-Wafa', 1981), 281.

${ }^{36}$ Madjid, "In search of Islamic Roots for Modern Pluralism", in Toward New Paradigm, ed. Mark R. Woodward (Arizona: Arizona State University, 1996), 101.

${ }^{37}$ Madjid, Islam Agama Peradaban, xv; idem, Islam, Doktrin dan Peradaban, 434-36; cf. Muhammad Shahrur, Al-Islam wa al-Iman: Manzumat al-Qiyam (Damascus: al-Ahali li al-Tiba'ah wa al-Nashr, 1996), 31-3.
} 
al-islām. $^{38}$

Although the message is the same, it does not follow that the language used to express the message is also the same. Nurcholish cites the Quran in this regard: "We sent not a messenger except (to teach) in the language of his (own) people in order to make (things) clear to them." Thus, the difference in the messages of the previous prophets and of the Prophet Muhammad lies only in language and not in substance. ${ }^{40}$ In addition, Nurcholish also recognizes that the difference in methods of expressing the message, as the Quran suggests (5: 48), occurs among the prophets due to the differences of place and time. In view of these differences, Nurcholish, following IbnTaymiyya, classifies "Islam" into "general" and "specific". The former indicates the religion of all previous prophets with their own methods and laws, while the latter refers to the Prophet Muhammad's religion with its own methods and laws owing to a different place and time. In other words, "specific Islam" is a continuation of and consistent with "general Islam."

Although there exist general principles among the "general Islam" and the "specific" one, Nurcholish says that this does not mean that human beings are free to embrace whatever religion. Rather, they have moral obligation to choose in accordance with the latest development, which is the "specific Islam" of the Prophet Muhammad. ${ }^{42}$

As with his idea of secularization, Nurcholish's interpretation of "Islam" also raises many serious critiques. Daud Rasyid, for example, strongly criticizes Nurcholish's interpretation of "Islam" and even condemns it as "a digression covered by scientific style." ${ }^{43}$ Rasyid argues that "Islam" as mentioned in the Quran is an organized religion revealed by God to the Prophet Muhammad. This interpretation is based on the Prophet's hadith: "Buniya al-Islam 'ala khams [Islam is built in five pillars] ..."44 This means that one can be considered a Muslim so far as he or she observes these five pillars, otherwise they are not Muslim. Moreover, the word "Muslim" applies only to the Prophet's followers and not to the followers of other religions. For example, the Quranic description of Abraham as hanīfa muslimā, is interpreted by Rasyid to mean a Muslim without any explanation. ${ }^{45}$ Ahmad Husnan proposes other critiques. Parallel to Rasyid's idea, "Islam" is meant to be the name of a religion. To support his idea, Husnan refers to the Quranic verse: "This day have I perfected your religion for you, completed my favour upon you, and have

\footnotetext{
${ }^{38}$ Ali, The Holy Quran, 150.

${ }^{39}$ Quran, 14:4; Ali, The Holy Quran, 604.

${ }^{40}$ Madjid, Islam Agama Peradaban, xiv.

${ }^{41}$ Madjid, Islam Agama Peradaban, xiv.

${ }^{42}$ Madjid, Islam Agama Peradaban, 2.

${ }^{43}$ Daud Rasyid, “Pembaruan” Islam dan Orientalisme dalam Sorotan (Jakarta: Usamah Press, 1993), 11.

${ }^{44}$ Rasyid, "Pembaruan" Islam dan Orientalisme, 46.

${ }^{45}$ Rasyid, "Pembaruan” Islam dan Orientalisme, 42.
} 
chosen for you Islam as your religion..."46. He also relies on the Prophetic hadith: "I favour upon Allah as God, Islam as religion and Muhammad as the Prophet and Messenger." ${ }^{47}$ Based on these references, he believes that "Islam" means nothing other than the religion of the Prophet Muhammad. In fact the objection underlying their critiques is the possibility of equation of Islam as a religion with the other religions. If "Islam" is meant to be simply a "submission to One God", then its shariah will be threatened. Moreover, without observing the shariah some people can claim to be Muslims even though they are from outside Islamic religion. Rasyid draws an example of Frans Magnis Suseno's statement: "My own personal hope is that I belong to Islam, although as a Christian I believe I do not belong to Islam." 48 Husnan, on the other hand, draws upon a statement of an orientalist, W.M. Watt: "I am not a Muslim, but I hope I am to be a Muslim meaning one who submits to God." ${ }^{49}$ Thus, in their view, there is no the difference between a Muslim as the Prophet Muhammad's follower and one who is not Muslim.

\section{The Notion of People of the Book (Ahl al-Kitāb)}

As mentioned before, "Islam" of the Prophet Muhammad is a continuation of previous religions. Therefore, it is obligatory for Muslims to believe in the prophets before him and in the scriptures revealed by God through them. The Quran refers to these communities as "the people of the book" (ahl al-kitāb). According to Nurcholish, ahl al-kitāb is a Quranic unique concept that recognizes the adherents of other religions who have the script ures to live and practice their teachings. ${ }^{50}$

Nurcholish maintains that ahl al-kitāb is often used to refer to Judaism and Christianity (al-yahüd wa al-nasārāa). This is because they are the first communities of scriptures that the followers of the Prophet Muhammad encounter. Moreover, their religions are immediate predecessors of Islam ${ }^{51}$. However, there is a controversy among Muslim scholars whether or not this concept includes other religious communities outsideJudaism and Christianity. Two other communities that the Quran refers to explicitly are the Majusi and the Sabeans:

Who those believe (in the Quran), and those who follow the Jewish (scriptures) and the Christians and the Sabeans and who believe in God and the Last Day and work righteousness, shall have their reward with their God; on them shall be no fear, nor shall they

\footnotetext{
${ }^{46}$ Husnan, Ilmiah Intelektual dalam Sorotan (Solo: Ulul Albab Press, 1993), 21.

${ }^{47}$ Husnan, Ilmiah Intelektual, 22.

${ }^{48}$ Rasyid, "Pembaruan” Islam dan Orientalisme, 47.

${ }^{49}$ Husnan, Ilmiah Intelektual, 17.

${ }^{50}$ Madjid, Islam Agama Peradaban, 69.

${ }^{51}$ Madjid, Islam Agama Peradaban, 72.
} 
grieve (Quran, 2:62). ${ }^{52}$

In Nurcholish's opinion, the Sabeans and Majusi are considered as ahl al-kitäb because the Prophet and his companions took from them the tax (jizyah) which was nottaken from the polytheists (al-mushrikūn). Following Muhammad Rashỉd Rị̣ā's opinion, Nurcholish maintains that the ahl al-kitäb can be extended to other communities that are not mentioned by the Quran, such as Hinduism, Buddhism and Confucianism. Ridâ's reason is that the Quran mentions Judaism, Christianity, Sabeans and Majusi due to the fact that these communities were well-known by the Prophet's early followers. If the Quran were to mention other communities that were never known by those people, it would be difficult for them to understand; it would be very strange (ighrāb)..$^{53}$

Nurcholish, moreover, argues for the application of the ahl al-kitāb to the other communities due to the fact that the Quran recognizes that God sent the prophets before Muhammad to every community and period, and gave them the scriptures. Some of them are mentioned in the Quran and others are not. Muslims have to believe in them and in their scriptures. Consequently, it is possible that the truth and scriptures can be found everywhere. Therefore, it is possible to extend ahl al-kitāb into other communities that were not mentioned in the Quran. Nurcholish also opines that ahl al-kitāb should be differentiated from polytheist communities. According to IbnTaymiyya, ahl al-kitāb cannot be identified as polytheists because their scriptures do not teach them polytheism. ${ }^{54}$

Parallel to the statement of the Quranic verse above, Nurcholish finally assumes the possibility of salvation of ahl al-kitāb so far as they believe in God and the Last Day and live righteously. Moreover, although most of ahl al-kitāb are strongly against Islam and the Prophet Muhammad, they are not all the same. ${ }^{55}$ This is suggested by other verses as follow:

Not all of them [ahl al-kitāb] are alike: of ahl al-kitāb are a portion that stand (for the right); they rehearse the signs of Allah all night long and they prostrate themselves in adoration. They believe in Allah and the Last Day; they enjoin what is the right, and forbid what is wrong; and they hasten (in emulation) in (all) good works: they are in the ranks of the righteous (Quran, 3: 113-4).

Again, Nurcholish's interpretation of ahl al-kitāb faces serious critiques, especially from Daud Rasyid and Ahmad Husnan. In response to Nurcholish's idea, Rasyid only questions the objectivity of Nurcholish in

\footnotetext{
${ }^{52}$ Ali, The Holy Quran, 33-4.

${ }^{53}$ Madjid, Islam Agama Peradaban, 82-3.

${ }^{54}$ Madjid, Islam Agama Peradaban, 83.

${ }^{55}$ Madjid, Islam Agama Peradaban, 76-7.
} 
quoting Rida's opinion. Rasyid believes that he does not find such a quotation in volume 2 of Rida's work. In fact, Nurcholish quotes from volume 4. Therefore, Nurcholish is correct in his quotation. ${ }^{56}$ Yet, Rasyid calls Nurcholish a liar and so on. ${ }^{57}$ Husnan's objection to Nurcholish's interpretation of ahl al-kitäb, on the other hand, is that it will bring about the possibility of marriage among different religious adherents. For if people are called ahl al-kitāb their women can marry Muslim men. Husnan believes that one of the methods of Christian missionary to convert Muslims into Christianity is through inter-religious marriage. ${ }^{58}$

Apart from these conflicting opinions, Nurcholish's interpretation of the meaning of "Islam" and ahl al-kitāb opens the possibility of salvation for the adherents of other religions. This indicates that Nurcholish's position toward religious diversity is not exclusive, since the exclusivists believe that salvation, liberation and whatever one considers to be the ultimate goal of religion is found solely in, or through, one particular religion. This means that adherents of other religions, though sincere in their religious practice and upright in their moral conduct, cannot obtain salvation through their religion ${ }^{59}$. However, Nurcholish also recognizes that the "Islam" of the Prophet Muhammad should be chosen morally for it is the latest development of "general Islam." This position is equivalent to the inclusivists' response to religious pluralism. Inclusivists claim the way of salvation is open to people only because they meet special criteria revealed in one true religion ${ }^{60}$. In this regard, Nurcholish emphasizes belief in One God, Last Day and righteous behaviour. Just as a Christian might speak of Christianity as the only true religion and of persons whose lives manifest the grace of God as "anonymous Christians," so the Muslim might speak of the absolute truth of Islam and of Christians and Jews as "anonymous Muslims" (Suseno, n.d.). Likewise, Nurcholish's position is different from the pluralists who claim that every religion can successfully facilitate salvation. John Hick, for example, draws an analogy between blind men understanding an elephant and different religions in capturing the Ultimate Reality. There is no one true understandingof the Reality, by the same token there is no understanding considered false ${ }^{61}$.

\section{CONCLUSION}

As a theologian, Nurcholish employs a theological approach in interpreting "Islam" and ahl al-kitäb. Since theology is concerned with basic and general concepts of religion, it is difficult for him to elaborate these

\footnotetext{
${ }^{56}$ M. Rasyid Rida, Tafsir al-Manar (Egypt: al-Hay’ah al-Misriyyah, 1973), 3: 156.

${ }^{57}$ Rasyid, "Pembaharuan Islam," 52.

${ }^{58}$ Husnan, Ilmiah Intelektual, 74-5.

${ }^{59}$ Peterson et.al., Reason and Religious Belief, 221-2.

${ }^{60}$ Peterson, Reason and Religious Belief, 228-9.

${ }^{61}$ Peterson, Reason and Religious Belief, 224.
} 
concepts in detail. Thus, he has performed his task. This is very different from Daud Rasyid and Ahmad Husnan who interpret the concepts from Islamic law. By interpreting the meaning of "Islam" and ahl al-kitāb Nurcholish wants to suggests that Islam is an inclusive religion that acknowledges the salvation of adherents of other religions. This also implies that Islam is very tolerant toward other religions.

Nurcholish's idea of inclusive theology is significantly important for religious pluralism in Indonesia, in particular, and for world religious diversity, in general. However, the virulent polemics his works incite indicate that such an idealistic vision will be difficult to realize. Therefore, it is necessary to develop his ideas with considerations of the critiques together.

\section{REFERENCES}

Ali, 'Abdullah Yusuf. The Holy Qur'an: Text, Translation and Commentary. Maryland, USA: Amana Corporation, 1989.

Ali, Fachry and Bahtiar Effendy. Merambah Jalan Baru Islam: Rekonstruksi Pemikiran Islam Masa Orde Baru. Bandung: Mizan, 1984.

Anshari, Endang Saefudin. Kritik atas Paham Sekularisasi dan Pembaharuan Drs. Nurcholish Madjid [A Critiques of Nurcholish Madjid's Concept of Secularization and Renewal]. Bandung: Bulan Sabit, 1973.

Azra, Azyumardi. "Cak Nur: Neo-Modemis atau Neo-Traditionalis". Unpublished paper.

Barton, Greg. "The Impact if neo-Modernism on Indonesia Islamic Thought," in Democracy in Indonesia: 1950s and 1990s, ed. David Bourchier and Jhon Leggs. Clayton: Monash University Center of Southeast Studies, 1994.

"Neo-Modernism: a Vital Synthesis of Traditionalist and Modernist Islamic Thought in Indonesia," Studia Islamika, 2:3 (1995): 1-75.

-------. "Indonesia's NurcholishMadjid and Abdurrahman Wahid as Intellectuals", Studia Islamika, 4:1 (1997).

Castles, Lance. "Notes on the Islamic School at Gontor," Indonesia, 1 (1996).

Geertz, Clifford. Islam Observed in Morocco and Indonesia. Chicago: The University of Chicago Press, 1971.

Hakiem, Lukman (ed.). Menggugat Gerakan Pembaruan Keagamaa: Debat Besar "Pembaruan Islam" [Charging Religious Renewal Movement: Great Debate of Islamic Renewal]. Jakarta: Lembaga Studi Informasi Pembangunan, 1995. 
Hassan, Muhammad Kamal. Muslim Intellectual Responses to the New Order Modernization in Indonesia. Kuala Lumpur: Dewan Bahasa dan Pustaka, 1982.

Hidayat, Komaruddin. "Kata Pengantar" [Preface] to Nurcholish Madjid's Islam Agama Peradaban: Membangun Makna dan Relevansi Doktrin Islam dalam Sejarah. Jakarta: Paramadina, 1995.

Husnan, Ahmad. Jangan Terjemahkan al-Qur'an menurut Visi Injil dan Orientalis [Don't Translate the Qur'an in the Light of Bible and Orientalist Vision]. Solo: UlulAlbab Press, 1987.

. Ilmiah Intelektual dalam Sorotan [Intellectual Scientific Ideas Reviewed]. Solo: Ulul Albab Press, 1993.

Liddle, William. Leadership and Culture in Indonesia Politics. Sydney: Asian Studies Association of Australia, 1996.

Madjid, Nurcholish. "Interview," Matra Magazine, 77 (December, 1992).

--------. Dialog Keterbukaan: Artikulasi Nilai Islam dalam Wacana Sosial Politik Kontemporer [Open Dialogue: an Articulation of Islamic Values in Contemporary Socio-Political Discourse]. Jakarta: Paramadina, 1998.

. "The Issue of Modernization among Muslims in Indonesia: From a Participant's Point of View," in What is Modern Indonesian Culture?, ed. Gloria Davis. Athens: Ohio University Press, 1979.

--------. Islam, Kemodernan dan Keindonesiaan [Islam, Modernity and Indonesian- ness]. Bandung: Mizan, 1987.

. Pintu-pintu Menuju Tuhan [Gates on the Path of God]. Jakarta: Paramadina, 1995.

. Islam, Doktrin dan Peradaban: Telaah Kritis tentang Masalah Keimanan, Kemanusiaan dan Kemodernan [Islam, Doctrin and Civilization: a Critical Study of Faith, Humanism and Modernity]. Jakarta: Paramadina, 1992.

---------. "Masalah Simbol dan Simbolisme dalam Ekspresi Keagamaan [Symbol and Symbolism in Religious Expression]," in Kontekstualisasi Doktrin Islam dalam Sejarah, ed. Budhy MunawarRahman. Jakarta: Paramadina, 1994.

--------. "In search of Islamic Roots for Modern Pluralism”, in Toward New Paradigm, ed. Mark R. Woodward. Arizona: Arizona State University, 1996.

--------. Islam Agama Peradaban: Membangun Makna dan Relevansi Doktrin Islam dalam Sejarah [Islam, Religion of Civilization: Developing a Sense of Islamic Doctrine in History and Its Relevance]. Jakarta: Paramadina, 1995.

Mastuhu. Dinamika Sistem Pendidikan Pesantren: Suatu Kajian tentang Unsur dan Nilai Sistem Pendidikan Pesantren. Jakarta: INIS, 1994. 
Muṭahharì, Murtaḍā. Al-'Adl al-Ilāhī, Arabic trans. by M. 'Abd al-Mun'im al-Khaqqānì. Beirut: Muassasat al-Wafá', 1984.

Nasr, Seyyed Hossein. Traditional Islam in the Modern World. London: KPI, 1987.

Islamic Life and Thought. Albany, NY: State University of New York, 1976.

Peterson, Michael, et. al. Reason and Religious Belief: an Introduction to the Philosophy of Religion. New York-Oxford: Oxford University Press, 1991.

Rahman, Fazlur. "Islam: Challenge and Opportunity," in Islam: Past Influence and Present Challenge, ed. Alford T. Welch and Pierre Cachia. New York: Edinburgh University Press, 1979.

Rasyid, Daud. Pembaruan" Islam dan Orientalisme dalam Sorotan [The Renewal of Islam and Orientalism Reviewed]. Jakarta: Usamah Press, 1993.

Rasyidi, H.M. Koreksi terhadap Drs. Nurcholish Madjid tentang Sekularisasi [Correction of Drs. Nurcholish Madjid's Secularization]. Jakarta: Bulan Bintang, 1972.

Riḍā, Muḥammad Rashīd. Tafsīr al-Manār, vol. 3. Egypt: al-Hay'ah alMișriyyah, 1973.

Saifullah H.A., Ali. "Daarussalaam: Pondok Modem Gontor," in Pesantren dan Pembaharuan, ed. M. DawamRahardjo. Jakarta: LP3ES, 1988.

Shahrūr, Muhammad. Al-Islām wa al-İmān: Manzūmat al-Qiyam. Damascus: al-AhāTi li al-Tibā'a ah wa al-Nashr, 1996.

Sirry, Mun'im. "Secularization in the Mind of Muslim Reformists: A Case Study of Nurcholish Madjid and Fouad Zakaria," Journal of Indonesian Islam, 1: 2 (2007): 323-355.

Suseno, Franz Magniz. "Islam, Agama Kemanusiaan: Pemikiran Keislaman Nurcholish Madjid.” Unpublished paper.

Woodward, Mark R. "Nurcholish Madjid," in The Oxford Encyclopedia of Modern Islamic World, ed. John L. Esposito, vol. 3. New York and London: Oxford University Press, 1995. 